\title{
Co-inoculation with Azospirillum brasilense in soybean cultivars subjected to water deficit
}

\author{
Alessandra M. de L. Naoe, Joênes M. Peluzio' ${ }^{1}$, Leonardo J. M. Campos² Lucas K. Naoe $^{3}$ \& \\ Roberta A. e Silva ${ }^{1}$ \\ ${ }^{1}$ Universidade Federal do Tocantins. Palmas, TO, Brasil. E-mail: alima@uft.edu.br (Corresponding author) - ORCID: 0000-0002-1271-8269; \\ joenesp@uft.edu.br - ORCID: 0000-0002-9336-2072; roberta.as@uft.edu.br - ORCID: 0000-0002-9682-3006 \\ ${ }^{2}$ Embrapa Soja. Londrina, PR, Brasil. E-mail: leonardo.campos@embrapa.br - ORCID: 0000-0002-8919-5398 \\ ${ }^{3}$ Universidade Estadual do Tocantins. Palmas, TO, Brasil. E-mail: lucas.kn@unitins.br - ORCID: 0000-0002-8662-4150
}

\begin{abstract}
This study aimed to verify the effect of co-inoculation, association between Azospirillum brasilense and Bradyrhizobium japonicum bacteria, on soybean plants subjected to water deficit at two sowing dates. Two field experiments were conducted at the Universidade Federal de Tocantins, campus of Palmas, Brazil, in 2016. The experimental design was randomized blocks in a split-split-plot arrangement with four repetitions, where the plots consisted of two irrigation depths (100 and 25\% of crop evapotranspiration ETc), the subplots was composed of two methods of inoculant application (inoculation with Bradyrhizobium japonicum and co-inoculation with Azospirillum brasilense + Bradyrhizobium japonicum) and the sub-subplots comprised two soybean cultivars (TMG 132 and ANTA 82). The cultivars responded differently to the sowing dates. Co-inoculation did not influence grain yield under full irrigation conditions (100\% ETc), in neither cultivar evaluated. However, under the water deficit condition ( $25 \%$ ETc), the grain yield of the cultivar TMG 132 increased 77.20\%, indicating that there are different responses of interaction between Azospirillum brasilense, plant genotype and sowing dates.
\end{abstract}

Key words: Glycine $\max (\mathrm{L}$.$) Merrill, rhizobacteria, water stress, irrigation$

\section{Coinoculação com Azospirillum brasilense em cultivares de soja submetidas a deficit hídrico}

RESUMO: Objetivou-se com este estudo verificar o efeito da coinoculação, associação entre as bactérias Azospirillum brasilense e Bradyrhizobium japonicum, em plantas de soja, submetidas a deficit hídrico em duas épocas de semeadura. Foram realizados dois experimentos em campo na Universidade Federal do Tocantins, campus de Palmas, no ano de 2016. O delineamento utilizado foi em blocos casualizados em esquema de parcelas sub-subdivididas com quatro repetições, onde as parcelas foram compostas por duas lâminas de irrigação (100 e 25\% da evapotranspiração da cultura - ETc), as sub-parcelas por dois métodos de aplicação de inoculantes (inoculação com Bradyrhizobium japonicum e coinoculação, com Azospirillum brasilense + Bradyrhizobium japonicum) e nas sub-subparcelas, duas cultivares de soja (TMG 132 e ANTA 82). As cultivares responderam de forma distinta às épocas de semeadura. A coinoculação não influenciou a produtividade de grãos em condições de irrigação plena (100\% ETc), em nenhuma cultivar avaliada. Entretanto, na condição de deficit hídrico (25\% ETc), a produtividade em grãos da cultivar TMG 132 aumentou em 77.20\%, indicando que há respostas distintas de interação entre o Azospirillum brasilense, genótipo da planta e datas de semeadura.

Palavras-chave: Glycine max (L.) Merrill, rizobactérias, estresse hídrico, irrigação 


\section{INTRODUCTION}

One of the major challenges of agriculture has been to find mechanisms that can reduce the effects of water deficit on crop yield, seeking technologies that increase productivity, even under unfavorable environmental conditions.

Plants respond to water deficit through various physiological and biochemical changes. Among the numerous adaptive traits, changes in root architecture are one of the most important under these conditions (Huang et al., 2014).

Thus, the association with plant growth-promoting rhizobacteria (PGPR) becomes an alternative, as these organisms are able to colonize the surface of the roots, stimulating their growth through biological nitrogen fixation and production of phytohormones, such as auxins, cytokinins and gibberellins (Zahedi \& Abbasi, 2015).

Within the large group of PGPR, the genus Azospirillum has been the focus of several studies related to abiotic stress and biological nitrogen fixation, especially the species Azospirillum brasilense (Rodrigues et al., 2015).

Many studies on the best application of Azospirillum brasilense are still being conducted, but some of them suggest that its use associated with Bradyrhizobium japonicum, known as co-inoculation, is more efficient when compared to the single inoculation of these bacteria (Gitti et al., 2012).

Studies conducted by Hungria et al. (2013) and Zahedi \& Abbasi (2015) indicate that soybean (Glycine max (L.) Merrill) plants co-inoculated with Azospirillum brasilense tolerated water stress better than control plants, besides showing higher nodulation and water content.

The present study was carried out to evaluate the effects of co-inoculation on the agronomic traits and grain yield of two soybean cultivars subjected to water deficit at two sowing dates.

\section{Material ANd Methods}

The study was conducted at the campus of the Universidade Federal de Tocantins, municipality of Palmas, TO, Brazil ( $10^{\circ} 10^{\prime} \mathrm{S}$ and $48^{\circ} 21^{\prime} \mathrm{W}$, at $216 \mathrm{~m}$ of altitude), from June to October 2016. Consecutive plantations were carried out on two sowing dates, the first one on June 2 (D1), 2016, and the second one on July 1, 2016 (D2).

Figure 1 presents the climatic data observed throughout both experiments.

The soil of the experimental area was classified as Oxisol, with loamy sand texture, showing $\mathrm{pH}$ of 4.9 , available concentrations of $\mathrm{P}$ and $\mathrm{K}$ of 3.00 and $26.00 \mathrm{mg} \mathrm{dm}^{-3}$, respectively; $\mathrm{Ca}$ and $\mathrm{Mg}$ concentrations of 1.5 and $0.7 \mathrm{cmol}_{\mathrm{c}} \mathrm{dm}^{-3}$, respectively, and base saturation equal to $54.44 \%$. The mean soil bulk density was $1.55 \mathrm{~kg} \mathrm{dm}^{-3}$, with sand, silt and clay percentage of 82,13 and $5 \mathrm{dag} \mathrm{kg}^{-1}$, respectively. The volumetric moisture values at field capacity and permanent wilting point were 0.33 and $0.12 \mathrm{~m}^{3} \mathrm{~m}^{-3}$, respectively.

The experimental design was randomized blocks in a split-split-plot arrangement with four repetitions. The plots consisted of two irrigation depths (L1 - 100\% ETc) and (L2 $25 \%$ ETc starting from pod formation stage R3), the subplots were used to evaluate the effect of the methods of inoculation (MI), and the sub-subplots were used to evaluate the effect of

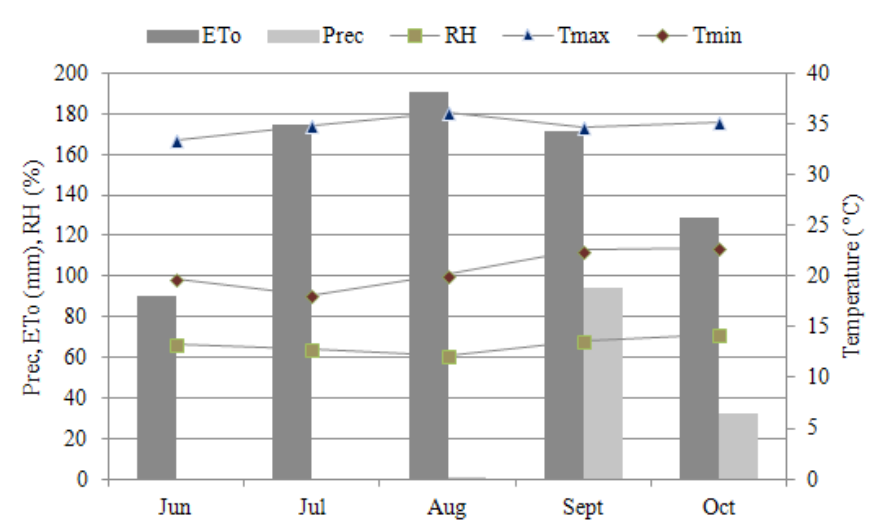

Figure 1. Mean values of maximum (Tmax) and minimum (Tmin) temperature $\left({ }^{\circ} \mathrm{C}\right)$, air relative humidity $(\mathrm{RH})$ and accumulated totals of reference evapotranspiration (ETo) and precipitation (Prec)

the cultivars ANTA 82 and TMG 132, of medium and early cycles, respectively.

The distribution uniformity of the irrigation system, which had drippers with flow rates of $1.7 \mathrm{~L} \mathrm{~h}^{-1}$ and were spaced by $20 \mathrm{~cm}$, was measured by the Christiansen test (CUC), presenting uniformity coefficient of $96.75 \%$.

The water volume applied to the treatments was estimated by the crop evapotranspiration (ETc) Eq. 1.

$$
\mathrm{ETc}=\mathrm{Kc} \text { ETo }
$$

where:

ETc - crop evapotranspiration, $\mathrm{mm} \mathrm{d}^{-1}$;

Kc - crop coefficient, dimensionless; and,

ETo - reference evapotranspiration, $\mathrm{mm} \mathrm{d}^{-1}$.

The Kc values adopted for soybean, according to its phenological stage, and ETo calculation followed the FAO Penman-Monteith method (Allen et al., 1998).

All treatments were equally irrigated during the crop establishment phase, trying to keep the soil moisture always close to field capacity.

Irrigation control started in the vegetative stage (V2). In the area corresponding to full irrigation (L1), there was replacement of the daily water depth of $100 \%$ ETc along the entire cycle; while in the area corresponding to L2, there was full replacement (100\% ETc) of the water depth until the R3 stage (beginning of pod formation), and from R3, there was a replacement of daily water depth of $25 \%$ ETc.

The methods of inoculation (MI) were applied in the furrow by direct spraying, immediately after sowing, and divided into: Inoculation (IN): dose of $600 \mathrm{~mL} 50 \mathrm{~kg}^{-1}$ of seed of Bradyrhizobium japonicum (Semia 5079 and Semia 5080 $5.0 \times 10^{9}$ viable cells per $\mathrm{mL} \mathrm{g}^{-1}$ ); Co-inoculation (CO): dose of $600 \mathrm{~mL} 50 \mathrm{~kg}^{-1}$ of seed of Bradyrhizobium japonicum/Semia + $400 \mathrm{~mL} \mathrm{ha}^{-1}$ of Azospirillum brasilense (AbV5 and AbV6 strains - $2.0 \times 10^{8}$ viable cells per $\mathrm{g}$ or $\left.\mathrm{mL} \mathrm{g}^{-1}\right)$.

The experimental plot consisted of four 5 -m-long rows at spacing of $0.50 \mathrm{~m}$ between rows and $1.0 \mathrm{~m}$ between treatments, with density of 15 plants per linear meter, totaling $897 \mathrm{~m}^{2}$.

Ten plants of each observation area were randomly harvested and evaluated for the characteristics total number 
of pods per plant (TPP) and 100-seed weight (100SW), at 13\% moisture content. Grain yield per hectare (GY) was calculated considering the observation area of the plot of $3 \mathrm{~m}^{2}$, eliminating the border effect.

The data were subjected to individual analysis of variance and, subsequently, to a joint analysis when the homogeneity of variances was verified.

The data that did not have normal distribution were transformed to square roots. Means were grouped by the test of Scott \& Knott (1974) at p $\leq 0.05$. The statistical program SISVAR 5.0 (Ferreira, 1998) was used.

\section{Results AND Discussion}

Table 1 presents the summary of the joint analysis of variance for soybean production and yield components. Due to the low applicability of the quadruple interactions, it was decided to adjust the degree of freedom of this interaction to the final residual, increasing its accuracy, as recommended by Gomes (2009). Thus, only double and triple interactions were considered in the analysis of variance.

Sowing dates (D), cultivars (C) and irrigation depths (L) had effect on all evaluated traits. Regarding the single effects of the methods of inoculation (MI), only 100-seed weight (100SW) was not affected.

For the double interaction MI x D, no significant effects were observed on any of the evaluated traits, so the sowing dates alone did not influence the establishment of inoculation and/or co-inoculation at planting. On the other hand, the interaction $\mathrm{C}$ $\mathrm{x} D$ caused effect on all traits, demonstrating that the cultivars had different behaviors as a function of sowing dates.

Table 1. Analysis of variance related to the characteristics: total number of pods per plant (TPP), 100-seed weight (100SW) and grain yield (GY) of the soybean cultivars (C), ANTA 82 and TMG 132, produced on two sowing dates (D) under two irrigation depths (L) and two methods of inoculation (MI)

\begin{tabular}{|c|c|c|c|c|}
\hline \multirow{2}{*}{ SV } & \multirow{2}{*}{ DF } & \multicolumn{3}{|c|}{ Mean square } \\
\hline & & TPP & 100 SW & GY \\
\hline D & 1 & $3.63^{*}$ & $7.75^{*}$ & $2056620.48^{*}$ \\
\hline Block & 3 & $0.33^{\mathrm{ns}}$ & $0.70^{\mathrm{ns}}$ & $29078.82^{\text {ns }}$ \\
\hline error 1 & 3 & 0.08 & 0.69 & 174265.15 \\
\hline L & 1 & $3.72^{\star}$ & $100.30^{*}$ & $6665827.37^{*}$ \\
\hline$L \times D$ & 1 & $0.62^{\text {ns }}$ & $4.88^{*}$ & $3207683.48^{*}$ \\
\hline error 2 & 6 & 0.30 & 0.57 & 75020.18 \\
\hline $\mathrm{MI}$ & 1 & $4.33^{*}$ & $0.44^{\mathrm{ns}}$ & $2372118.45^{\star}$ \\
\hline $\mathrm{MI} \times \mathrm{L}$ & 1 & $0.33^{\mathrm{ns}}$ & $0.06^{\mathrm{ns}}$ & $572861.54^{*}$ \\
\hline $\mathrm{MI} \times \mathrm{D}$ & 1 & $1.14^{\mathrm{ns}}$ & $0.12^{\mathrm{ns}}$ & $220280.72^{\text {ns }}$ \\
\hline$M I \times L \times D$ & 1 & $0.06^{\mathrm{ns}}$ & $1.34^{\mathrm{ns}}$ & $28556.88^{\text {ns }}$ \\
\hline error 3 & 6 & 0.38 & 1.01 & 73497.44 \\
\hline C & 1 & $110.99 *$ & $3.52^{*}$ & $26070431.22^{\star}$ \\
\hline$C \times D$ & 1 & $3.18^{*}$ & $85.51^{*}$ & $409800.76^{*}$ \\
\hline$C \times L$ & 1 & $0.00^{\text {ns }}$ & $0.30^{\mathrm{ns}}$ & $265885.71^{*}$ \\
\hline $\mathrm{C} \times \mathrm{Ml}$ & 1 & $0.01^{\mathrm{ns}}$ & $1.05^{\mathrm{ns}}$ & $835417.49 *$ \\
\hline$C \times D \times L$ & 1 & $0.01^{\mathrm{ns}}$ & $7.85^{\star}$ & $1137249.15^{\star}$ \\
\hline $\mathrm{C} \times \mathrm{MI} \times \mathrm{L}$ & 1 & $0.37^{\mathrm{ns}}$ & $0.79^{n s}$ & $1079471.78^{\star}$ \\
\hline $\mathrm{C} \times \mathrm{Ml} \times \mathrm{D}$ & 1 & $0.01^{\mathrm{ns}}$ & $0.51^{\mathrm{ns}}$ & $109864.48^{\text {ns }}$ \\
\hline error 4 & 31 & 0.11 & 0.31 & 63585.64 \\
\hline $\mathrm{CV}_{1} \%$ & & 4.81 & 5.77 & 2.25 \\
\hline $\mathrm{CV}_{2} \%$ & & 8.96 & 5.26 & 8.87 \\
\hline $\mathrm{CV}_{3} \%$ & & 10.08 & 6.97 & 6.73 \\
\hline $\mathrm{CV}_{4} \%$ & & 5.31 & 3.88 & 5.72 \\
\hline
\end{tabular}

* Significant at $\mathrm{p} \leq 0.05$ by F test; $\mathrm{ns}$ - Not significant; DF - Degrees of freedom SV - Source of variation
The double interaction L $x$ D had effects on the traits 100SW and GY. The double interactions MI x L, C x L and C x MI only caused significant effects on yield.

In the triple interaction MI x L x D, none of the studied traits responded to the effects in a significant way. Similarly, for the interaction $\mathrm{C} \times \mathrm{MI} \times \mathrm{D}$, there were no differences of response between cultivars, regarding the inoculant application method and sowing dates.

For $\mathrm{C} \times \mathrm{MI}$ x L, the yield proved to be sensitive and was affected by the effects of this interaction. The cultivars behaved differently in response to the irrigation depths, inoculation and/ or co-inoculation. This information is extremely important for the choice of materials that are more tolerant to water deficit and respond better to the use of biological inoculants, hence serving as a tool for management programs that can guide the planting and conduction of crops.

The interaction C $\mathrm{x}$ D x L was significant for the characteristics 100SW and GY, emphasizing the need to conduct tests in more than one planting period and water management.

Table 2 shows the means for the total number of pods per plant (TPP), resulting from the analysis of the double interaction $\mathrm{C} \times \mathrm{D}$.

On both sowing dates, the cultivar TMG 132 showed higher total number of pods per plant (49.88 and 63.63). According to Garcia et al. (2007), soybean cultivars respond in a particular way to the sowing date. This can occur depending on cycle duration, sensitivity to photoperiod, duration of the juvenile period or type of growth.

For the cultivar ANTA 82, no significant differences were observed in TPP between the first and second sowing dates. These results suggest that this cultivar has shown greater plasticity for a possible compensation among the production components (Procópio et al., 2014). Another explanation would be the earliness of the cultivar and the shorter cycle, so there was not enough time to respond differently in relation to this characteristic.

On the other hand, the cultivar TMG 132 showed higher mean of TPP for the second date (63.63). Generally, the sowing date induces phenological and morphological modifications, including in the production components, such as number of pods and grains. However, these modifications are not always reflected in grain yield due to the compensation between components (Peixoto et al., 2000). According to the authors, in many situations, there is no compensation in the production components that can counterbalance very intense effects of the environment, so one trait may be favored to the detriment of another, with loss in the final yield.

Therefore, the fact that the cultivar TMG 132 had higher mean of TPP for the second sowing date does not guarantee

Table 2. Means of total number of pods per plant (TPP), of two soybean cultivars produced on two sowing dates, in the 2016 off-season

\begin{tabular}{ccc}
\hline \multirow{2}{*}{ Cultivars } & \multicolumn{3}{c|}{ TPP } \\
\cline { 2 - 3 } & D1 & D2 \\
ANTA 82 & $23.85 \mathrm{bA}$ & $23.91 \mathrm{bA}$ \\
TMG 132 & $49.88 \mathrm{aB}$ & $63.63 \mathrm{aA}$ \\
\hline
\end{tabular}

Means followed by the same lowercase letter in the column and uppercase letter in the row do not differ by the Scott-Knott test at $\mathrm{p} \leq 0.05$; D1- Sowing date 1 (Jun 2, 2016); D2 - Sowing date 2 (July 1, 2016) 
that it can achieve higher yield under these conditions, since this trait depends on the plant's capacity to fill the pods with grains.

Table 3 presents the means for 100-seed weight (100SW), resulting from the analysis of the triple interaction $\mathrm{C} \times \mathrm{D} \times \mathrm{L}$.

The means comparison test showed that the cultivars had the highest 100-seed weight in the treatments without water deficit, L1 (100\% ETc), regardless of the sowing date, and obtained lower means of 100SW in L2 (25\% ETc).

Similar results were found by França Neto et al. (2012), who observed a reduction in the average 100 -seed weight in soybean cultivars under water deficit. According to a study conducted by Gava et al. (2015), on the physiological responses of soybean under water deficit, in the grain filling stage, the deficit may cause a reduction in the average grain weight, which corroborates the results obtained. However, the analysis of the cultivars for each sowing date (Table 3 ) revealed that, for D1, the cultivar ANTA 82 obtained higher means of 100SW (16.24 and 13.75), regardless of water availability. In this case, it is suggested that the environmental conditions recorded for D1 favored this cultivar, which did not occur for D2.

For the second date (D2), the behavior was inverted and the cultivar TMG 132 was the one with highest average seed weight under both irrigation conditions (16.72 and 15.61). Santos et al. (2003) also found difference in grain weight between soybean cultivars, indicating that there is a great variation between them for this characteristic.

Theoretically, the conditions recorded for D2 (high temperature combined with water deficit) would negatively affect the production components. Under unfavorable environmental conditions, the plant tries to favor one trait to the detriment of another, so the increase of 100SW observed in the cultivar TMG 132, for the second sowing date, has possibly led to reduction of other traits.

Lana (1996) states that limiting environmental conditions cause intense competition between different plant parts for nutrients and metabolites. This competition is particularly substantial during the formation of reproductive structures, resulting in a compensatory variation among the primary components of production.

For França Neto et al. (2012), changes in the supply of assimilates can be explained by many of the environmental effects, in which genetic differences are probably regulated by the seed. In addition, the 100-grain weight is a genetically determined trait, but it is also influenced by the environment (Mauad et al.,2010).

Table 4 presents the means of grain yield, resulting from the analysis of the triple interaction $\mathrm{C} \times \mathrm{D} \times \mathrm{L}$.

Table 3. Means of 100-seed weight (100SW) of two soybean cultivars subjected to two irrigation depths, for two sowing dates, in the 2016 off-season

Means of 100-seed weight followed by the same lowercase letter in the column and uppercase letter in the row do not differ by the Scott-Knott test at $\mathrm{p} \leq 0.05$; Means of 100 -seed weight followed by the same number in the row do not differ by the Scott-Knott test at $\mathrm{p} \leq 0.05$; L1 - Irrigation depth $1(100 \% \mathrm{ETc})$; L2 - Irrigation depth $2(25 \% \mathrm{ETc})$; D1- Sowing date 1 (June 2, 2016); D2 - Sowing date 2 (July 1, 2016)

\begin{tabular}{|c|c|c|c|c|}
\hline \multirow{3}{*}{ Cultivars } & \multicolumn{2}{|c|}{ D1 } & \multicolumn{2}{|c|}{$\overline{D 2}$} \\
\hline & \multicolumn{4}{|c|}{$1005 W(g)$} \\
\hline & L1 & $\mathrm{L2}$ & $\mathrm{L1}$ & $\mathrm{L} 2$ \\
\hline ANTA 82 & $16.24 \mathrm{aA} 1$ & $13.75 \mathrm{aB} 1$ & 14.78 bA2 & 11.99 bB2 \\
\hline TMG 132 & $14.96 \mathrm{bA} 2$ & $11.34 \mathrm{bB} 2$ & $16.72 \mathrm{aA} 1$ & $15.61 \mathrm{aB} 1$ \\
\hline
\end{tabular}

Table 4. Means of grain yield (GY) of two soybean cultivars subjected to two irrigation depths, for two sowing dates, in the 2016 off-season

\begin{tabular}{|c|c|c|c|c|}
\hline \multirow{3}{*}{ Cultivars } & \multicolumn{2}{|c|}{ D1 } & \multicolumn{2}{|c|}{ D2 } \\
\hline & \multicolumn{4}{|c|}{ GY (kg ha-1) } \\
\hline & L1 & L2 & $\overline{\mathrm{L1}}$ & $\overline{\mathrm{L} 2}$ \\
\hline ANTA 82 & $1467.09 \mathrm{bA} 1$ & 769.40 bB1 & $1087.46 \mathrm{bA} 2$ & 752.06 bB1 \\
\hline TMG 132 & $3299.12 \mathrm{aA} 1$ & $1810.40 \mathrm{aB} 1$ & $2066.21 \mathrm{aA} 2$ & $2006.20 \mathrm{aA} 1$ \\
\hline & y the same & se letter in & $\begin{array}{l}0.05 ; \mathrm{Ll}-\mathrm{Ir} \\
\text { date } 1 \text { (June }\end{array}$ & $\begin{array}{l}\text { case letter in the } \\
\text { the same number } \\
\text { on depth } 1 \text { ( } 100 \% \\
\text { 16); D2 - Sowing }\end{array}$ \\
\hline
\end{tabular}

Under all management conditions adopted, the cultivar TMG 132 had higher means of grain yield.

The analysis of irrigation depths, for each cultivar and within each sowing date, showed that for the first sowing date (D1) the two cultivars recorded higher yield in L1 (100\% ETc). Water deficit in L2 (25\% ETc) caused reductions of 47 and $45 \%$ in the mean yield of the cultivars ANTA 82 and TMG 132 , respectively.

For the second sowing date (D2), L2 (25\% ETc) caused a $30.84 \%$ reduction in the cultivar ANTA 82. Eck et al. (1987) determined the effect of water deficit on soybean in environments of low water availability and reported production loss of about $46 \%$ for deficits between stages R1 and R5 (early flowering and grain filling).

On the other hand, the cultivar TMG 132, for the second sowing date (D2), showed no difference in the mean yield between the irrigation depths, demonstrating greater tolerance to the water deficit imposed. This situation was observed for TMG 132 only for the second sowing date, suggesting that other factors may be involved in the different behavior of this cultivar in relation to the environmental variations.

When there was effect of sowing dates, for each irrigation depth, both cultivars had the same behavior, that is, for L1 (100\% ETc), the period after the first sowing date was more favorable for yield, whereas for L2 (25\% ETc), the sowing date did not influence this characteristic. In addition, there were effects of the triple interaction $\mathrm{C} \mathrm{x} \mathrm{MI} \mathrm{x} \mathrm{L} \mathrm{on} \mathrm{grain} \mathrm{yield}$ (Table 5).

The effect of irrigation depths, for each cultivar and method of inoculation, led to higher grain yield always under conditions of good water availability (L1). Probably, the presence of more favorable water conditions for plant development and survival of bacteria has favored the process of biologic nitrogen fixation. Under more suitable environmental conditions, there would

Table 5. Means of grain yield (GY) of two soybean cultivars subjected to two irrigation depths, inoculated with Bradyrhizobium japonicum (IN) or co-inoculated with Bradyrhizobium japonicum + Azospirillum brasilense (CO), in the 2016 off-season

\begin{tabular}{|c|c|c|c|c|}
\hline \multirow{3}{*}{ MI } & \multicolumn{2}{|c|}{$\mathrm{L} 1$} & \multicolumn{2}{|c|}{$\mathrm{L} 2$} \\
\hline & \multicolumn{4}{|c|}{ GY (kg ha $\left.a^{-1}\right)$} \\
\hline & IN & CO & IN & CO \\
\hline ANTA 82 & 1163.74 bA1 & 1390.81 bA1 & 717.72 bA2 & 803.74 bA2 \\
\hline TMG 132 & $2600.37 \mathrm{aA} 1$ & $2764.96 \mathrm{aA} 1$ & $1377.04 \mathrm{aB2}$ & $2439.55 \mathrm{aA} 2$ \\
\hline
\end{tabular}

R. Bras. Eng. Agríc. Ambiental, v.24, n.2, p.89-94, 2020. 
be better nodulation of the roots by $\mathrm{N}$-fixing bacteria, such as Bradyrhizobium.

Despite that, both cultivars obtained yield means lower than their production potential. This may have occurred due to the sowing dates, in which the climatic conditions did not favor the good development of the crop.

The analysis of the methods of inoculation (MI) for each cultivar, within each irrigation depth, showed that in L1 (100\% ETc) there was no significant effect of yield gain related to coinoculation. This demonstrates that, under this condition, the presence of Azospirillum brasilense did not interfere with this trait. These results corroborate the studies by Braccini et al. (2016) and Zuffo et al. (2016), who worked with the application of Azospirillum brasilense and Bradyrhizobium japonicum in soybean and found no difference in the mean yield between inoculated and co-inoculated treatments.

On the other hand, the cultivar TMG 132, when subjected to $\mathrm{L} 2(25 \% \mathrm{ETc})$, from the stage R3, had a $77.20 \%$ increase of yield $(2439.55 \mathrm{~kg})$ in the treatment co-inoculated with Azospirillum brasilense, compared to the inoculated treatments $(1377.04 \mathrm{~kg})$, for the same irrigation depth.

In studies carried out with soybean using inoculation and co-inoculation, in two different sites, Hungria et al. (2013) reported that at the site where severe water deficit occurred, the observed gains in yield were more substantial in the treatments with co-inoculation, although the losses were greater.

Creus et al. (2004) found that wheat plants inoculated with Azospirillum and under water stress conditions had higher hydration, water potential and apoplastic water fraction than control plants, under the same conditions. In addition, the authors observed that, under water restriction conditions, the yield was less affected in plants inoculated with the bacterium.

There is evidence that microorganisms can select a different metabolic pathway, depending on the environment (Patten \& Glick, 1996), which could explain the fact that the effects of co-inoculation were more substantial under water stress conditions.

For Dimkpa et al. (2009), these bacteria can mediate changes in the elasticity of root cell walls, which would be one of the first steps to improve tolerance to water stress, in addition to increasing the production of auxins and abscisic acid in situations of drought, contributing to attenuating the reductions of yield.

The difference observed between the cultivars in relation to the methods of inoculation (IN and CO) possibly occurred due to the plant-bacterium interaction. According to Matsumura et al. (2015), inoculation response may vary according to plant genotype, bacterial strain and environmental conditions. This variability of results between cultivars and bacterial interaction has also been observed by other authors, which may be related to the genetic traits intrinsic to each soybean genotype.

\section{Conclusions}

1. The total number of pods was influenced by the sowing date, only in the cultivar TMG 132.

2. Both cultivars had higher 100-seed weight under full irrigation, regardless of sowing date.
3. Co-inoculation with Azospirillum brasilense only succeeded in increasing grain yield, during water deficit and only for the cultivar TMG 132, demonstrating that genetic materials exhibit different responses.

\section{Literature Cited}

Allen, R. G.; Pereira, L. S.; Raes, D.; Smith, M. Crop evapotranspiration: Guidelines for computing crop water requirements. Rome: FAO, 1998. 301p. Irrigation and Drainage, Paper 56

Braccini, A. L.; Mariucci, G. E. G.; Suzukawa, A. K.; Lima, L. H. S.; Piccinin, G. G. Co-inoculação e modos de inoculação de Bradyrhizobium japonicum e Azospirillum brasilense e adubação nitrogenada na nodulação das plantas e rendimento da cultura da soja. Scientia Agraria Paranaensis, v.15, p.27-35, 2016. https:// doi.org/10.18188/1983-1471/sap.v15n1p27-35

Creus, C. M.; Sueldo, R. J.; Barassi, C. A. Water relations and yield in Azospirillum-inoculated wheat exposed to drought in the field. Review Canadian Journal of Botanic, v.2, p.273-281, 2004. https:// doi.org/10.1139/b03-119

Dimkpa, C.; Weinand, T.; Asch, F. Plant-rhizobacteria interactions alleviate abiotic stress conditions. Plant, Cell and Environment, v.32, p.1682-1694, 2009. https://doi.org/10.1111/j.1365-3040.2009.02028.x

Eck, H. V.; Mathers, A. C.; Musick, J. T. Plant water stress at various growth stages and growth and yield of soybeans. Field Crops Research, v.17, p.1-16, 1987. https://doi.org/10.1016/03784290(87)90077-3

Ferreira, D. F. Sisvar: Sistema de análise de variância para dados balanceados. Lavras: UFLA, 1998. 19p.

França Neto, J. B.; Pádua, G. P. de; Krzyzanowski, F. C.; Carvalho, M. L. M. de;.Henning, A. A.; Lorini, I. Semente esverdeada de soja: Causas e efeitos sobre o desempenho fisiológico - Série sementes. Londrina: Embrapa Soja 2012. 16p. Circular Técnica, 91

Garcia, A.; Pípolo, A. E.; Lopes, I. de O. N.; Portugal, F. A. Instalação da lavoura de soja: Época, cultivares, espaçamento e população de plantas. Londrina: Embrapa Soja, 2007. 10p. Circular Técnica 51

Gava, R.; Frizzone, J. A.; Snyder, R. L.; José, J. V.; Fraga Junior, E. F.; Perboni, A. Estresse hídrico em diferentes fases da cultura da soja. Revista Brasileira de Agricultura Irrigada, v.9, p.349-359, 2015. https://doi.org/10.7127/rbai.v9n600368

Gitti, D. C.; Arf, O.; Kaneko, F. H.; Rodrigues, R. A. F.; Buzetti, S.; Portugal, J. R.; Corsini, D. C. D. C. Inoculação de Azospirillum brasilense em cultivares de feijões cultivados no inverno. Revista Agrarian, v. 5, p.36-46, 2012.

Gomes, F. P. Curso de estatística experimental. 15.ed. Piracicaba: FEALQ, 2009. 451p.

Huang, B.; Costa, M. da; Jiang, Y. Research advances in mechanisms of turfgrass tolerance to abiotic stresses: From physiology to molecular biology. Critical Reviews Plant Sciences, v.33, p.141189, 2014. https://doi.org/10.1080/07352689.2014.870411

Hungria, M.; Nogueira, M. A.; Araújo, R. S. Co-inoculation of soybeans and common beans with rhizobia and azospirilla: Strategies to improve sustainability. Biology Fertility of Soils, v.49, p.791-801, 2013. https://doi.org/10.1007/s00374-012-0771-5

Lana, A. M. Q. Avaliação de linhagens de feijão obtidas pelo método de melhoramento single seed descent (ssd) nos sistemas de plantio em monocultivo e consórcio com o milho. Viçosa: UFV, 1996. 125p. Tese Doutorado 
Matsumura, E. E.; Secco, V. A.; Moreira, R. S.; Santos, O. J. P.; Hungria, M.; Oliveira, A. L. M. Composition and activity of endophytic bacterial communities in field-grown maize plants inoculated with Azospirillum brasilense. Annals of Microbiology, v.1, p.1-14, 2015.

Mauad, M.; Silva, T. L. B.; Almeida Neto, A. I.; Abreu, V. G. Influência da densidade de semeadura sobre características agronômicas na cultura da soja. Revista Agrarian, v.3, p.175-181, 2010.

Patten, C. L.; Glick, B. R. Bacterial biosynthesis of indole-3-acetic acid. Canadian Journal of Microbiology, v.42, p.207-220, 1996. https://doi.org/10.1139/m96-032

Peixoto, C. P.; Câmara, G. M. S.; Martins, M. C.; Marchiori, L. F. S.; Guerzoni, R. A.; Mattiazzi, P. Épocas de semeadura e densidade de plantas de soja: I. Componentes da produção e rendimento de grãos. Scientia Agricola, v.57, p.89-95, 2000. https://doi. org/10.1590/S0103-90162000000100015

Procópio, S. O.; Balbinot Junior, A. A.; Debiasi, H.; Franchini, J. C.; Panison, F. Semeadura em fileira dupla e espaçamento reduzido na cultura da soja. Revista Agro@mbiente On-line, v.8, p.212-221, 2014. https://doi.org/10.18227/1982-8470ragro.v8i2.1469
Rodrigues, A. C.; Bonifácio, A.; Araújo, F. F.; Lira Júnior, M. A.; Figueiredo, M. V. B. Azospirillum sp. as a challenge for agriculture. Sustainable Development and Biodiversity, v.12, p.29-51, 2015. https://doi.org/10.1007/978-3-319-24654-3_2

Santos, J. M. B.; Peixoto, C. P.; Santos J. M. B.; Brandelero, E. M.; Peixoto, M. F. S. P.; Silva V. Desempenho vegetativo e produtivo de cultivares de soja em duas épocas de semeadura no Recôncavo Baiano. Magistra, v.15, p.111-121, 2003.

Scott, A. J.; Knott, M. A cluster analysis methods for grouping means in the analysis of variance. Biometrics, v.30, p.507-512, 1974. https://doi.org/10.2307/2529204

Zahedi, H.; Abbasi, S. Effect of plant growth promoting rhizobacteria (PGPR) and water stress on phytohormones and polyamines of soybean. Indian Journal. Agriculture Research, v.49, p.427-431, 2015. https://doi.org/10.18805/ijare.v49i5.5805

Zuffo, A. M. Bruzi, A. T.; Rezende, P. M.; Bianchi, M. C.; Zambiazzi, E. V.; Soares, I. O.; Ribeiro, A. B. M.; Vilela, G. B. L. Morphoagronomic and productive traits of RR soybean due to inoculation via Azospirillum brasilense groove. African Journal of Microbiology Research, v.10, p.438-444, 2016. https://doi.org/10.5897/AJMR2015.7682 